\title{
Activation of a $\beta$-Tubulin Gene during Early Development of the Plasmodium in Physarum polycephalum
}

\author{
By LILIANNA SOLNICA-KREZEL,* WILLIAM F. DOVE AND \\ TIMOTHY G. BURLAND \\ McArdle Laboratory for Cancer Research, University of Wisconsin, 450 N. Randall Ave., \\ Madison, WI 53706, USA
}

(Received 24 November 1987)

\begin{abstract}
Uninucleate amoebae of Physarum polycephalum strain CL undergo apogamic development to form multinucleate plasmodia via an intermediate stage of large, uninucleate cells irreversibly committed to plasmodial development. This amoebal-plasmodial transition involves major changes in tubulin gene expression and the organization of microtubular structures. We analysed the expression of the betC locus, which encodes the plasmodial-specific $\beta 2$-tubulin, during plasmodial development. A key question addressed was the timing of expression of betC in relation to the last open mitosis of the amoeba and the first closed mitosis of the plasmodium during the transition. Culture conditions were improved to yield partly synchronous differentiating cultures containing $50-60 \%$ committed cells, in order to facilitate biochemical analysis of development. Northern blotting indicated that betC RNA was virtually absent from amoebae and from early differentiating cultures. However, betC transcripts could already be detected in differentiating cultures containing only $0.1 \%$ of committed cells; the relative amount of betC transcripts increased as the percentage of committed cells in differentiating cultures increased. In fully developed plasmodia, there was at least a 330 -fold increase in the betC transcript level compared to that in amoebae. We conclude that betC is activated during the amoebal-plasmodial transition immediately before or during the commitment event. Small amounts of $\beta 2$-tubulin polypeptide could first be detected by Western blotting around the stage of the first closed mitosis. Thus $\beta 2$-tubulin may participate in the first closed mitosis that committed cells undergo during their development into plasmodia.
\end{abstract}

\section{INTRODUCTION}

$\alpha$-and $\beta$-tubulins are the principal protein components of microtubules, fibres that participate in a variety of cellular structures, including the cytoskeleton, centrioles, mitotic and meiotic spindles, and flagellar axonemes. Most eukaryotes express multiple $\alpha$ - and $\beta$-tubulin genes with distinct products. The different tubulin genes in a family usually exhibit different patterns of expression. Developmentally regulated genes have been identified for both $\alpha$-and $\beta$-tubulins (e.g. Theurkauf et al., 1986; Havercroft \& Cleveland, 1984). Analysis of the expression of tubulin genes during development can thus be used to address the more general issue of how differential gene expression is regulated. A more specific problem is whether the changes in the pattern of expression of stage-specific tubulin genes are necessary for the developmental transition to occur.

The myxomycete Physarum polycephalum exhibits a life cycle with several alternative cell types and developmental transitions (Dee, 1975, 1987), facilitating studies of the timing of specific developmental changes. This paper is concerned with the expression of the $\beta$-tubulin gene betC during the development of uninucleate amoebae into multinucleate plasmodia. In $P$. polycephalum strain CL, amoebae form plasmodia in clones (Von-Stosch et al., 1964; Wheals, 1970). The process is apogamic (Cooke \& Dee, 1974; Anderson et al., 1976). CL amoebae grow 
and differentiate on agar plates with bacteria as a food source. In differentiating cultures of CL, amoebae grow and divide until they reach a certain cell density, at which time a presumptive extracellular inducing activity reaches a certain concentration (Youngman et al., 1977; Nader et al., 1984) and plasmodial development begins. Detailed cinematographic and cytological studies have revealed that uninucleate $\mathrm{CL}$ amoebae form multinucleate plasmodia via the following distinct intermediate stages: (1) uninucleate cells that have lost the amoebal characteristic of ability to form flagellates but that are still unable to form plasmodia at low cell density and temperatures above $30^{\circ} \mathrm{C}$ (Blindt et al., 1986); (2) uninucleate cells irreversibly committed to plasmodial development (these committed cells are defined by their ability to develop into plasmodia independent of density and temperature: Youngman et al., 1977); (3) binucleate cells able to fuse with other cells; (4) small multinucleate plasmodia (Anderson et al., 1976; Bailey et al., 1987). Cells that have lost the ability to form flagellates become committed to plasmodial development after approximately the next $5 \mathrm{~h}$ of differentiation. The first closed mitosis then occurs $8 \mathrm{~h}$ after commitment (Blindt et al., 1986; Dee, 1987).

The amoebal-plasmodial transition involves substantial morphological and physiological alterations as well as major changes in gene expression (Anderson et al., 1986). Biochemical differences between the amoebal and plasmodial stages of the Physarum life cycle have been described at the protein (Turnock et al., 1981) and RNA levels (Pallotta et al., 1986; Sweeney et al., 1987). However, among many stage-specific genes, only a few have been functionally identified. For example, amoebae and plasmodia exhibit distinct stage-specific heavy myosin chains (Kohama et al., 1984) as well as different $\alpha$ - and $\beta$-tubulin isotypes (Burland et al., 1983).

Major changes in organization of microtubular structures accompany changes in tubulin gene expression during the amoebal-plasmodial transition. Of the three $\beta$-tubulin genes, one is amoeba-specific (the betA locus) (Burland et al., 1984), one is plasmodium-specific (the betC locus) (Burland et al., 1988) and one is expressed in both amoebae and plasmodia (the bet $B$ locus) (Burland et al., 1984). In amoebae, microtubules participate in the cytoplasmic cytoskeleton, the centrioles and the mitotic spindle. In plasmodia, the only microtubular structure detected is the mitotic spindle. Open mitosis occurs in amoebae whereas closed mitosis is observed in plasmodia (Havercroft \& Gull, 1983) and in the first division that committed cells undergo. The amoebal-plasmodial transition thus provides opportunities to examine the hypotheses that distinct $\alpha$ - and $\beta$-tubulin isotypes may show functional specificity (Fulton \& Simpson, 1976) or that distinct tubulin genes may facilitate distinct modes of regulation in different cell types (Raff, 1984). A key question in the context of these hypotheses is the timing of accumulation of the plasmodium-specific $\beta 2$-tubulin in relation to the transition between the open mitosis of the amoeba and the closed mitosis of the plasmodium.

Blindt et al. (1986) developed a method to enrich differentiating cultures for committed cells. When developing cells are suspended in water, amoebae convert into flagellates, while cells undergoing development do not. Flagellates and nonflagellates can then be fractionated by glass-bead column chromatography. The enriched population can continue development with partial synchrony when transferred to liquid medium (Blindt et al., 1986). Using this method, Blindt et al. (1986) reported that the plasmodium-specific $\beta 2$-tubulin was absent from committed cells. This result implied that the first closed mitosis during the amoebal-plasmodial transition can occur in the absence of $\beta 2$-tubulin.

In this work we describe a method to improve the synchrony of development of $\mathrm{CL}$ amoebae on plates, to yield populations containing up to $60 \%$ of committed cells, with little contamination of cells in other stages of development. Using these cultures, we have analysed both the level of transcripts and accumulation of the polypeptide product of the plasmodiumspecific betC $\beta 2$-tubulin gene during the amoebal-plasmodial transition. The results lead to a significant revision of previous estimates of the earliest stage during development at which $\beta 2$ tubulin can be detected.

\section{METHODS}

Media. DSDM (dilute semi-defined medium) and LIA (liver infusion agar) were as described by Blindt et al. (1986) and SBS (standard bacterial suspension) of Escherichia coli was as described by Burland et al. (1981).

Strain. The $P$. polycephalum strain used in this study was the apogamic mutant CL (Colonia Leicester; Cooke \& 
Dee, 1974). Amoebal stocks were cultured on LIA plates at $30^{\circ} \mathrm{C}$ as described by Blindt et al. (1986); this temperature is restrictive to plasmodium development. Differentiation was carried out at $26^{\circ} \mathrm{C}$.

Differentiation conditions. CL cysts were plated on DSDM plates with $0.1 \mathrm{ml}$ SBS in an inoculum of $5 \mathrm{~cm}$ diameter. The plates were incubated at $26^{\circ} \mathrm{C}$ for $48 \mathrm{~h}$, respread with $0.5 \mathrm{ml}$ water, and incubated further at $26^{\circ} \mathrm{C}$ for the next $18 \mathrm{~h}$ as described by Blindt et al. (1986). Sometimes respreading was omitted. Growth and differentiation were monitored in each culture by taking periodic haemacytometer counts of suspensions made by washing the cultures from the plates in a known volume of water. At each time point the percentage of committed cells was assayed by plating and the percentage of binucleates was estimated by counting binucleate cells per 200500 cells in culture. Differentiating cultures for RNA isolation or protein samples were started from about $5 \times 10^{5}$ cysts and incubated at $26^{\circ} \mathrm{C}$ for $30-60 \mathrm{~h}$ to obtain cultures with $0-60 \%$ of committed cells.

Enrichment for committed cells by glass-bead column chromatography. Cells were harvested from differentiation plates started from $10^{5}$ cysts, flagellate formation was induced and the population was enriched in committed cells by glass-bead column chromatography as described by Blindt et al. (1986).

RNA blotting. RNA was isolated by the modified guanidinium thiocyanate method described by Burland et al. (1983). Total RNA was glyoxalated and electrophoresed for $9 \mathrm{~h}$ on $1.7 \%(w / v)$ agarose gels as described by Schedl et al. $(1984 b)$. Blotting of RNA from agarose gels to Biodyne A nylon membranes and hybridization were performed as described by Schedl et al. $(1984 a)$. Actin filters were washed six times for 20 min in $1 \times$ SSC at $55^{\circ} \mathrm{C}$; tubulin filters three times for $20 \mathrm{~min}$ in $1 \times \mathrm{SSC}$ and three times for $20 \mathrm{~min}$ in $0.5 \times \mathrm{SSC}$, at $55^{\circ} \mathrm{C}(1 \times \mathrm{SSC}$ is $0.15 \mathrm{M}-\mathrm{NaCl} / 0.015 \mathrm{M}$-sodium citrate, $\mathrm{pH} 7 \cdot 0$ ).

Gel electrophoresis and immunoblotting. Two-dimensional gels were run as described by Burland et al. (1983) with modifications described by Diggins \& Dove (1987). Proteins were transferred to nitrocellulose by the method of Towbin et al. (1979) with modifications described by Diggins \& Dove (1987). The transfer was run for $12 \mathrm{~h}$ at 100 mA. Immunoblotting was done as described by Birkett et al. (1985). The primary antibody used was KMX-1, a monoclonal mouse IgG antibody specific for $\beta$-tubulin raised against $P$. polycephalum tubulin (Birkett et al., 1985). The secondary antibodies used were affinity-purified, peroxidase-conjugated goat anti-mouse IgG (Boehringer Mannheim Biochemicals).

\section{RESULTS AND DISCUSSION}

\section{Improving synchrony in differentiating cultures}

In order to establish when during the amoebal-plasmodial transition particular genes are switched on or off, it is desirable to obtain large populations of cells in each of the intermediate stages of plasmodial development.

We obtained differentiating cultures containing a high percentage of committed cells by two methods. In method 1, that described by Blindt et al. (1986), approximately $10^{5} \mathrm{CL}$ cysts were plated on DSDM agar plates in an inoculum of about $5 \mathrm{~cm}$ diameter and differentiation was carried out at $26^{\circ} \mathrm{C}$ with or without subsequently respreading the growing cells over the plates. After $67 \mathrm{~h}$ of differentiation, when the cultures contained about $30 \%$ of committed cells, all cells were harvested. Flagellate development was induced and the population was enriched for committed cells by glass-bead column chromatography (Blindt et al., 1986). The method yielded populations containing $80 \%$ (our results) or even $90 \%$ (Blindt et al., 1986) of committed cells. However, only $50 \%$ of committed cells were obtained in the enriched population when larger numbers of cells were applied to the columns. Moreover, no more than $10^{7}$ cells could be applied to one column, which made processing large numbers of cells difficult. The glass-bead column chromatography also led to some cell loss (Table 1). Because analysis of RNA and proteins is facilitated by having large numbers of cells, we looked for an alternative method that would yield at least $5 \times 10^{7}$ committed cells per time point, with minimal contamination of cells in other stages of development. We devised a method (method 2) that favours a more synchronous development on plates, precluding the need for enrichment on glass-bead columns. Knowing that the amoebal-plasmodial transition is a density-dependent process, we asked if differentiation started from a higher-density inoculum of CL cysts would be more synchronous. Fig. $1(a)$ shows the kinetics of appearance of committed cells in two differentiating cultures grown from inocula of $10^{5}$ and $5 \times 10^{5}$ cysts per plate. Differentiation began earlier in the culture started from larger numbers of cysts, and the percentage of committed cells also increased faster. During $10 \mathrm{~h}$ of differentiation, the proportion of committed cells increased from 1 to $13 \%$ in the culture started from $10^{5}$ cysts, versus from 0.25 to $30 \%$ in that started from 

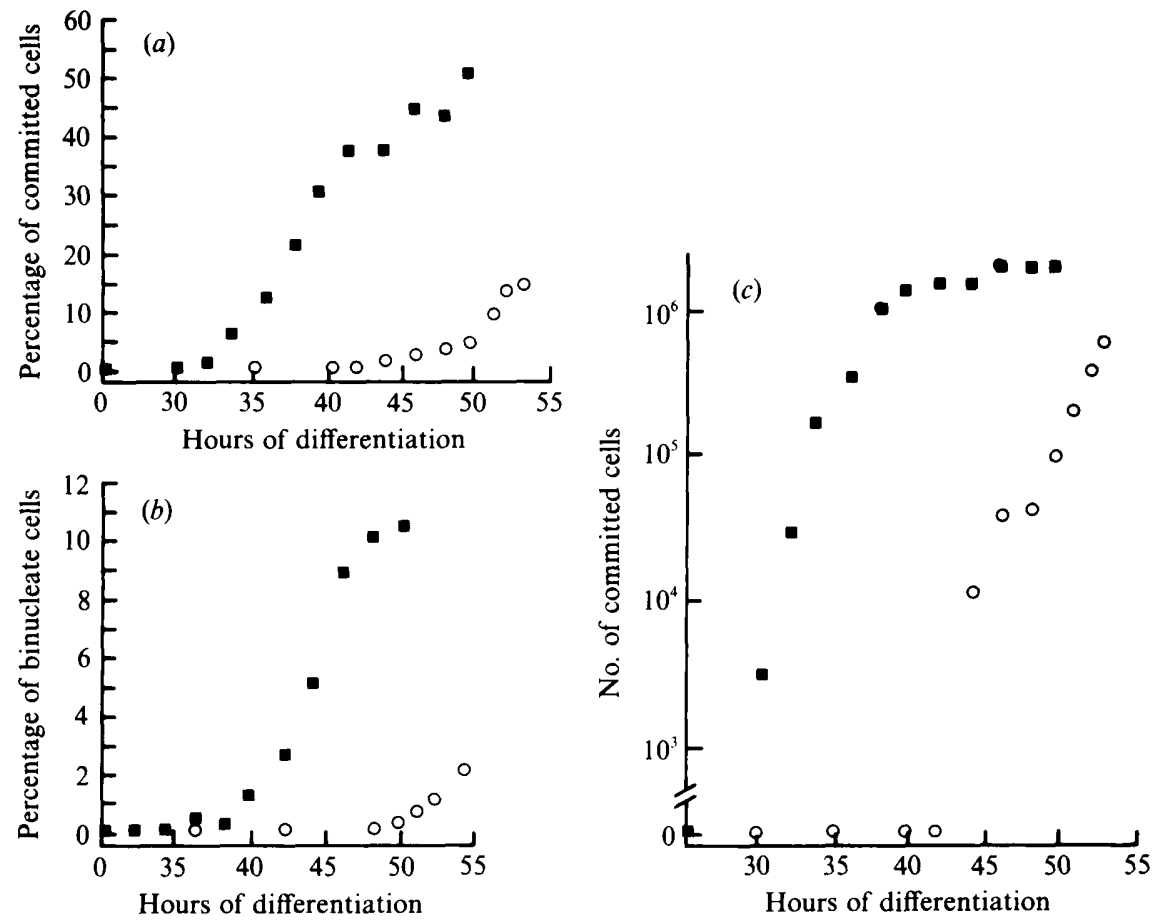

Fig. 1. (a) Percentage of committed cells during the amoebal-plasmodial transition in differentiating $\mathrm{CL}$ cultures started from $1 \times 10^{5}(\mathrm{O})$ and $5 \times 10^{5}(\boldsymbol{D})$ cysts. At the indicated time points of differentiation, cells from one plate in each series were harvested and the percentage of committed cells was established. (b) Percentage of binucleate cells during the amoebal-plasmodial transitions in differentiating cultures started from $1 \times 10^{5}(O)$ and $5 \times 10^{5}(\square)$ CL cysts. $(c)$ Kinetics of plasmodial development in cultures of amoebae on plates started from $1 \times 10^{5}(\mathrm{O})$ and $5 \times 10^{5}(\square)$ CL cysts.

\section{Table 1. Comparison of two methods for enrichment in committed cells}

In method 1, differentiation was started from $10^{5}$ cysts per inoculum, flagellate formation was induced, then the cell population was enriched in committed cells by glass-bead column chromatography. In method 2, differentiation was started from $5 \times 10^{5}$ cysts per inoculum, then cells were washed and used directly for assays. The table shows typical results obtained from several experiments. See text for details.

$\begin{array}{ccccccc}\text { Method } & \begin{array}{c}\text { Hours of } \\ \text { differentiation }\end{array} & \begin{array}{c}\text { No. of cells } \\ \text { harvested }\end{array} & \begin{array}{c}\text { Initial } \\ \text { no. of } \\ \text { committed } \\ \text { cells }\end{array} & \begin{array}{c}\text { Final } \\ \text { percentage of } \\ \text { committed } \\ \text { cells }\end{array} & \begin{array}{c}\text { Final no. of } \\ \text { committed } \\ \text { cells }\end{array} & \begin{array}{c}\text { Percentage of } \\ \text { committed } \\ \text { cells } \\ \text { recovered }\end{array} \\ & 66 & 9 \times 10^{7} & 2.6 \times 10^{7} & 45 & 1.1 \times 10^{7} & 42 \\ 2 & 67 & 1.8 \times 10^{8} & 3.4 \times 10^{7} & 48 & 2.5 \times 10^{7} & 73 \\ & 55 & 7.8 \times 10^{7} & 4.1 \times 10^{7} & 52 & 4.1 \times 10^{7} & 100 \\ & 56 & 1.1 \times 10^{8} & 7.0 \times 10^{7} & 64 & 6.7 \times 10^{7} & 95\end{array}$

$5 \times 10^{5}$ cysts. Fig. $1(b)$ shows the percentage of binucleates as a function of time of differentiation in each culture. By comparison of the kinetics of development of committed cells with that of binucleates for each culture, it is possible to estimate the interval between commitment and the first closed mitosis. Using this approach, we found that this interval was about 7-9 $\mathrm{h}$ and was independent of the number of cysts plated. This observation is in good agreement with previous work (Blindt et al., 1986). 
In differentiating cultures started from $10^{5}$ cysts, the first binucleate cells appeared when there were about $4 \%$ of committed cells, whereas in cultures started from $5 \times 10^{5}$ cysts, the first binucleates $(\sim 0 \cdot 1-0 \cdot 2 \%)$ were detected when there were $10-20 \%$ of committed cells. The time at which the proportion of binucleate cells reached $1 \%$ corresponded to quite different stages in the formation of committed cells: $13 \%$ in the low-density culture and $30 \%$ in the high-density culture. Thus, differentiation was more synchronous when a larger inoculum was used. Fig. $1(c)$ shows the total number of committed cells harvested from one plate at different times of differentiation for two differentiating cultures. These plots confirm that differentiation begins much earlier in cultures started from larger inocula. After $48-50 \mathrm{~h}$ of differentiation, in cultures started from $5 \times 10^{5} \mathrm{CL}$ cysts, the number of committed cells harvested from a single plate stopped rising (Fig. 1c), or even fell (other experiments, not shown). This can probably be explained by previous observations that binucleate cells, present at this stage of differentiation, are able to fuse with other cells and to ingest amoebae (Anderson et al., 1976). As a consequence, the total number of cells harvested at later stages of differentiation does not increase (data not shown). The number of amoebae decreases due both to transition into committed cells and to ingestion by binucleate cells (Youngman et al., 1977). The number of committed cells does not change substantially, but the percentage of committed cells still increases (see also Blindt et al., 1986). Therefore, although the cultures started from $5 \times 10^{5}$ cells contain about $60 \%$ of committed cells after $55 \mathrm{~h}$ of development, they should not be used as a source for committed cells because of the high percentage of binucleate and multinucleate cells. These might well exhibit a pattern of gene expression different from that of uninucleate committed cells.

Table 1 shows a comparison of the two methods used to obtain populations of differentiating cells in which a high percentage of cells are committed to plasmodium development. Method 2 yields up to four times more committed cells than method 1 relative to the number of cells harvested from differentiating plates; $95-100 \%$ of committed cells present in the harvested population of cells can be recovered in method 2 , but only $42-73 \%$ in method 1 . Method 2 also reduces the perturbations involved in method 1, including induction of flagellates $(4 \mathrm{~h})$ and glass-bead column chromatography $(2 \mathrm{~h})$. Therefore, in subsequent experiments we used differentiating cultures started from $5 \times 10^{5}$ cysts and differentiation was carried out without respreading.

\section{The betC locus encoding plasmodium-specific $\beta 2$-tubulin is expressed in committed cells}

To establish the point during the amoebal-plasmodial transition at which transcripts from the bet $C$ locus can first be detected, total RNA was isolated from cells after different times of development. A separate culture was used for each RNA sample preparation as follows. Sample 1 , taken at $38 \mathrm{~h}$, contained $<0.1 \%$ of committed cells; at this stage of development the differentiating culture contains mainly amoebae and cells that are unable to form flagellates. Other samples were taken at $40 \mathrm{~h}$ (sample $2-0.1 \%$ of committed cells, $<0.2 \%$ of binucleates; sample $3-2 \%$ of committed cells, $<0.2 \%$ of binucleates), $45 \mathrm{~h}$ (sample $4-8 \%$ of committed cells, $<0.2 \%$ of binucleates), $50 \mathrm{~h}$ (sample $5-14 \%$ of committed cells, $<0.2 \%$ of binucleates) and $55 \mathrm{~h}$ (sample $6-36 \%$ of committed cells, $4 \%$ of binucleates; sample $7-52 \%$ of committed cells, $\sim 8 \%$ of binucleates). The differences in percentage of committed cells in cultures ( 2 versus $3 ; 6$ versus 7) after the same time of differentiation may reflect small differences in inoculum size and/or temperature, to which differentiation is very sensitive. As a control, total RNA was isolated from amoebal cultures incubated at $30^{\circ} \mathrm{C}$, a temperature restrictive for the amoebalplasmodial transition. RNA was also isolated from CL microplasmodia obtained from CL amoebae. Each RNA sample $(3 \mu \mathrm{g})$ was electrophoresed on two parallel $1.7 \%$ agarose gels and blotted to Biodyne A nylon filters. One filter was probed with a DNA probe specific for the betC locus (Burland et al., 1988), and the other with a $P$. polycephalum actin cDNA probe (Knoerzer $e t$ $a l ., 1986)$. Fig. 2 shows the resulting autoradiograms. Transcripts complementary to the betC locus were virtually absent from amoebal RNA and abundant in plasmodial RNA. Densitometric analysis showed that the signal obtained from plasmodial RNA was at least 330fold stronger than that from amoebal RNA. The bet $C$ transcripts were also virtually absent from differentiating cultures at the stage of development just preceding commitment $(<0 \cdot 1 \%$ of 

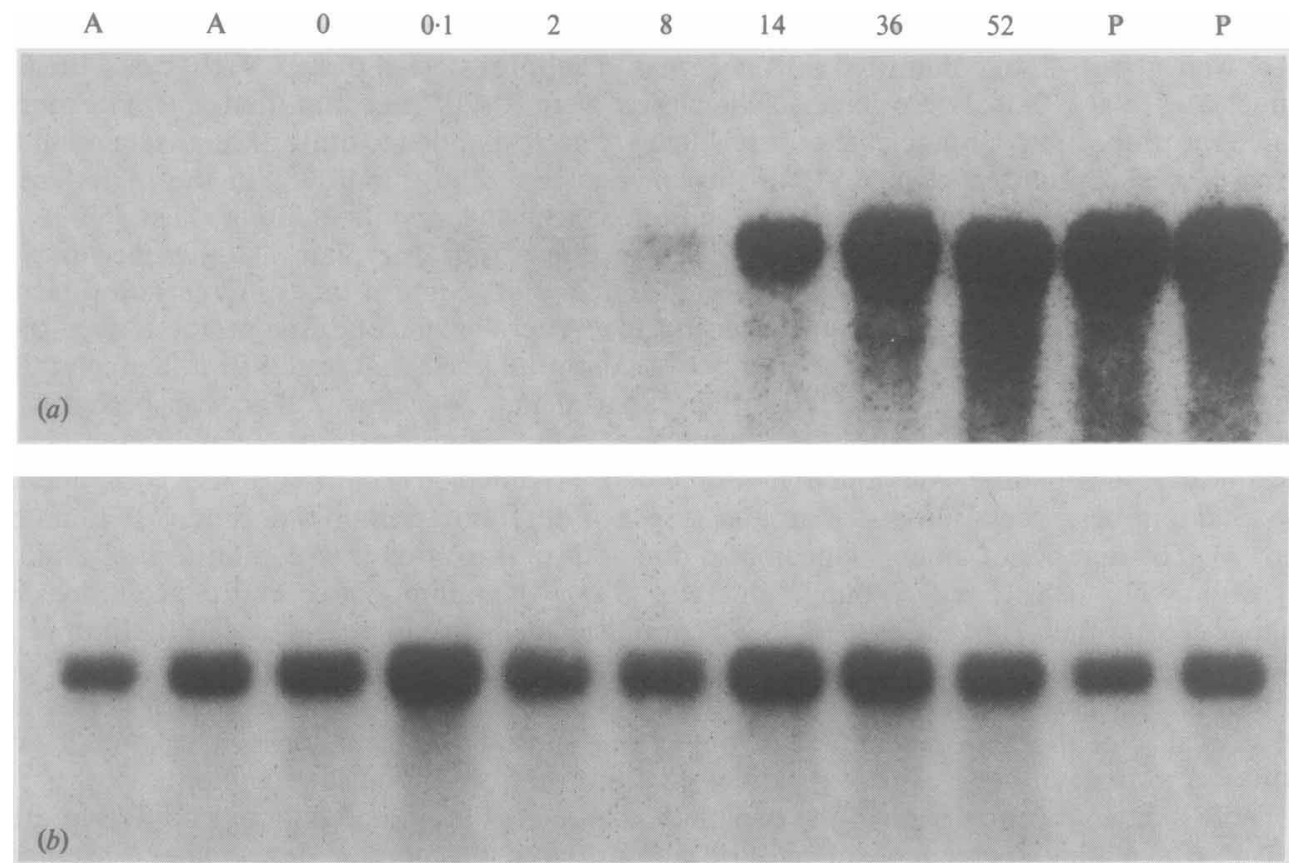

Fig. 2. Northern blot analysis of betC RNA $(a)$ and actin RNA $(b)$ during the amoebal-plasmodial transition. Total RNA ( $3 \mu \mathrm{g}$ samples electrophoresed) was isolated from CL amoebae (A), from differentiating cultures with different percentages of committed cells $(0,0 \cdot 1,2,8,14,36$ and $52 \%)$ and from CL microplasmodia (P). Exposure for $\beta 2$-tubulin RNA was for $8 \mathrm{~d}$ at $-70^{\circ} \mathrm{C}$ with a DuPont Lightning Plus intensifying screen; for actin RNA it was for $24 \mathrm{~h}$ at room temperature.

committed cells). A trace of signal could be detected in RNA isolated from differentiating cultures containing only $0.1 \%$ or $2 \%$ committed cells. The relative amount of betC transcripts increased as the percentage of committed cells increased. The signal obtained in RNA from a culture containing $52 \%$ of committed cells was 300 -fold stronger than that in amoebal RNA and therefore constituted $90 \%$ of the signal obtained in plasmodial RNA. It is important to note that betC transcripts were already abundant $(40 \%$ of the plasmodial signal) in cultures containing only $14 \%$ of committed cells where binucleate cells were still absent $(<0 \cdot 2 \%)$. In contrast, the relative levels of actin transcripts were similar in amoebae, in differentiating cultures and in plasmodia (Fig. 2b). It is concluded that the transcripts from the betClocus start to accumulate during the amoebal-plasmodial transition immediately before or during the commitment event.

\section{Detection of the plasmodium-specific $\beta 2$-tubulin at early stages of plasmodium development}

Knowing that the bet $C$ locus is active in committed cells, we looked for its product, $\beta 2$ tubulin, in early differentiating cultures. Previous results suggested that uninucleate committed cells did not yet express the plasmodium-specific tubulin isotypes $\alpha 2$ and $\beta 2$, although after $96 \mathrm{~h}$ incubation of committed cells, microplasmodia were present in the culture and the tubulin isotypes were in a similar pattern to that found in plasmodia (Blindt et al., 1986). Using the highdensity method of synchronous differentiation of $C L$ amoebae, more material was obtained for protein analysis. Fig. 3 shows a Western blot of CL proteins, probed with a monoclonal antibody, $\mathrm{KMX}-1$, specific for $\beta$-tubulins; $5 \times 10^{6}$ amoebae and $10^{7}$ cells from differentiating cultures were analysed in this experiment. Only $\beta 1$-tubulin was present in amoebae, whereas both $\beta 1$ - and $\beta 2$-tubulins were present in plasmodia (Burland et al., 1983; Fig. 3). In differentiating cultures, large amounts of $\beta 1$ - and small amounts of $\beta 2$-tubulin were present (Fig. 3). 

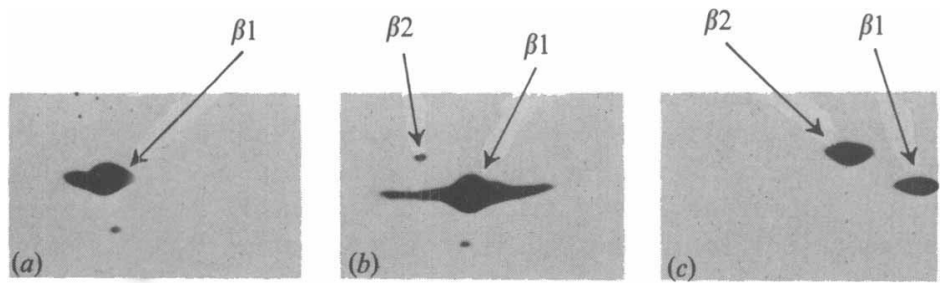

Fig. 3. Expression of $\beta$-tubulin isotypes in $\mathrm{CL}$ amoebae $(a)$, in a differentiating culture containing $42 \%$ of committed cells and $1-2 \%$ of binucleates $(b)$, and in CL microplasmodia $(c)$. Whole-cell extracts were resolved on two-dimensional gels: isoelectric focussing was from left (basic) to right (acidic), and SDSPAGE from top to bottom. Proteins were transferred to nitrocellulose filters by electroblotting, and the filters were probed with monoclonal antibody KMX-1, specific for $\beta$-tubulins. $\beta 1, P$. polycephalum $\beta 1$ tubulin isotype; $\beta 2, P$. polycephalum $\beta 2$-tubulin isotype.

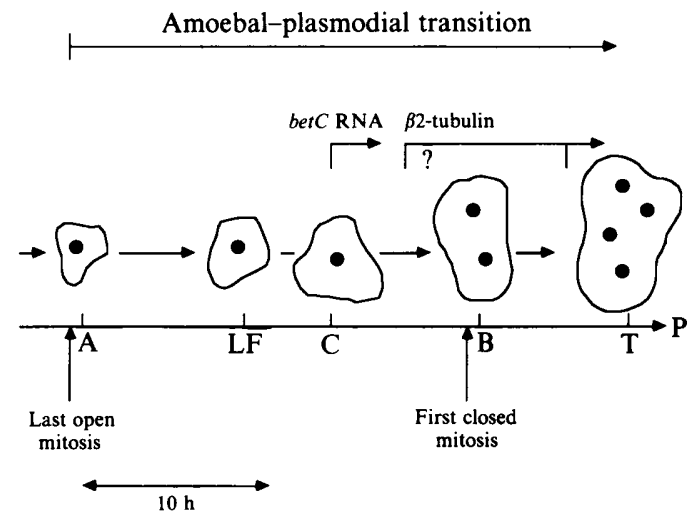

Fig. 4. Time course of cellular (Dee, 1987) and molecular events during apogamic development. In differentiating cultures of $\mathrm{CL}$, amoebae (A) grow and divide by open mitosis. When the cell density reaches a certain level, plasmodial development begins. Some cells lose the ability to form flagellates (LF), become committed to plasmodium formation (C) and finally become binucleate (B) by an intranuclear mitosis, without cytokinesis. Further closed mitoses lead to the formation of the syncytial plasmodium (P).

The cell cycle between the last open mitosis (amoebal type) and the first closed mitosis (plasmodial type), during which amoebae become committed to plasmodium development, is at least twice as long as the normal amoebal cell cycle: $20 \mathrm{~h}$ versus 8-10 $\mathrm{h}$ (Fig. 4) (Bailey et al., 1987). Our results show that transcripts from the betC locus begin to accumulate at the time of the commitment event, i.e. about $8 \mathrm{~h}$ before closed mitosis. By contrast, $\beta 2$-tubulin appears to accumulate much later in this transitional cell cycle, only shortly before mitosis. This would explain why the culture in which $\beta 2$-tubulin can first be detected already contains a small proportion of binucleates. However, it is possible that the initial accumulation of $\beta 2$-tubulin polypeptide may lie below the level of detection, giving only an apparent delay in accumulation. If, alternatively, $\beta 2$-tubulin were synthesized only after the first closed mitosis, at the stage of binucleate cells, its synthesis might well be narrowed to an approximately $2 \mathrm{~h}$ window just before the second closed mitosis (Fig. 4), since this is the observed time of tubulin synthesis in mature plasmodia (Laffler et al., 1981; Schedl et al., 1984b). In this case, the culture in which $\beta 2$-tubulin was detected should have contained a small proportion of quadrinucleate cells. These, however, could not be detected in this culture $(<0 \cdot 1 \%)$.

Thus, we speculate that $\beta 2$-tubulin accumulates in uninucleate committed cells shortly before the first closed mitosis and therefore can participate in the mitotic spindle formed during this process. The participation of $\beta 2$-tubulin in the very first intranuclear mitotic spindle would 
support the hypothesis of existence of tubulin isotypes specialized to specific microtubular structures. However, the possibility that $\beta 2$-tubulin is synthesized only by binucleate cells can not yet be rigorously excluded.

Expression of other plasmodium-specific genes, with unknown functions, has also been reported to occur at the commitment stage of the amoebal-plasmodial transition (Sweeney et al., 1987). The plasmodium-specific heavy myosin chain is easily detectable with polyclonal antibodies in uninucleate differentiating cells (Uyeda \& Kohama, 1987). It is now important to determine which developmental changes are necessary for the completion of the amoebalplasmodial transition.

We are grateful to M. A. Diggins and L. Green for help in initiating this work. We thank J. Dee for access to unpublished results and R. Braun, D. Cunningham, M. Diggins, L. Larson, E. C. A. Paul and A. B. Blindt for helpful discussions and comments. Work was supported by Program-Project grant CA-23076 and core grant CA-07175 from the National Institutes of Health. L.S.-K. was supported by the Graduate School of the University of Wisconsin - Madison.

\section{REFERENCES}

Anderson, R. W., CoOKe, D. J. \& DeE, J. (1976). Apogamic development of plasmodia in the myxomycete Physarum polycephalum: a cinematographic analysis. Protoplasma 89, 29-40.

Anderson, R. W., DeE, J. \& Gull, K. (1986). Cellular transformations of myxamoebae. In Molecular Biology of Physarum polycephalum, pp. 111-130. Edited by W. F. Dove et al. New York \& London: Plenum Press.

Bailey, J., Anderson, R. W. \& DeE, J. (1987). Growth and development in relation to the cell cycle in Physarum polycephalum. Protoplasma 141, 101-111.

Birkett, C. R., Foster, K. E., Johnson, L. \& Gull, K. (1985). Use of monoclonal antibodies to analyze the expression of a multigene family. FEBS Letters 187, $211-218$.

Blindt, A. B., Chainey, A. M., Dee, J. \& Gull, K. (1986). Events in the amoebal plasmodial transition of Physarum polycephalum studied by enrichment for committed cells. Protoplasma 132, 149-159.

Burland, T. G., Chainey, A. M., Dee, J. \& Foxon, J. L. (1981). Analysis of development and growth in a mutant of Physarum polycephalum with defective cytokinesis. Developmental Biology 85, 26-38.

Burland, T. G., Gull, K., Schedl, T., Boston, R. S. \& Dove, W. F. (1983). Cell type-dependent expression of tubulins in Physarum. Journal of Cell Biology 97, 1852-1859.

Burland, T. G., Schedl, T., Gull, K. \& Dove, W. F. (1984). Genetic analysis of resistance to benzimidazoles in Physarum: differential expression of $\beta$ tubulin genes. Genetics 108, 123-141.

Burland, T. G., Paul, E. C. A., Oetliker, M. \& Dove, W. F. (1988). A spindle-specific $\beta$-tubulin gene in Physarum. Molecular and Cellular Biology 8 , 1275-1281.

COOKe, D. J. \& DEE, J. (1974). Plasmodium formation without change in nuclear DNA content in $P h y$ sarum polycephalum. Genetical Research 23, 307-317.

DEE, J. (1975). Slime moulds in biological research. Science Progress 62, 523-542.

DEE, J. (1987). Genes and development in Physarum. Trends in Genetics 3, 208-213.

Diggins, M. A. \& Dove, W. F. (1987). Distribution of acetylated $\alpha$-tubulin in Physarum polycephalum. Journal of Cell Biology 104, 303-309.
Fulton, C. \& Simpson, P. A. (1976). Selective synthesis and utilization of flagellar tubulin: the multi-tubulin hypothesis. In Cell Motility, pp. 9871005. Edited by R. Goldman, T. Pollard \& J. Rosenbaum. Cold Spring Harbor, NY : Cold Spring Harbor Press.

Havercroft, J. C. \& Cleveland, D. W. (1984). Programmed expression of $\beta$-tubulin genes during development and differentiation of the chicken. Journal of Cell Biology 99, 1927-1935.

Havercroft, J. C. \& Gull, K. (1983). Demonstration of different patterns of microtubule organization in Physarum polycephalum myxamoebae and plasmodia, using immunofluorescence microscopy. European Journal of Cell Biology 32, 67-74.

KNOERZER, W. (1986). PhD thesis, University of Munich.

Kohama, K. \& Takano-Ohmuro, H. (1984). Stagespecific myosins from amoeba and plasmodium of slime mold, Physarum polycephalum. Proceedings of the Japanese Academy 60, 431-434.

Laffler, T. G., Chang, M. T. \& Dove, W. F. (1981). Periodic synthesis of microtubular proteins in the cell cycle of Physarum. Proceedings of the National Academy of Sciences of the United States of America 78, 5000-5004.

Nader, W. F., Shipley, G. L., Huettermann, A. \& HolT, C. E. (1984). Analysis of an inducer of the amoebal-plasmodial transition in the myxomycetes Didydium iridis and Physarum polycephalum. Developmental Biology 103, 504-510.

Pallotta, D., Laroche, A., Tessier, A., Shinnick, T. \& LemieuX, G. (1986). Molecular cloning of stage specific mRNAs from amoebae and plasmodia of Physarum polycephalum. Biochemistry and Cell Bio$\log y$ 64, 1294-1302.

RAFF, E. C. (1984). Genetics of microtubule systems. Journal of Cell Biology 99, 1-10.

SChedl, T., OWens, J., Dove, W. F. \& Burland, T. G. $(1984 a)$. Genetics of the tubulin gene families of Physarum. Genetics 108, 143-164.

Schedl, T., Burland, T. G., Gull, K. \& Dove, W. F. $(1984 b)$. Cell cycle regulation of tubulin RNA level, tubulin protein synthesis and assembly of microtubules in Physarum. Journal of Cell Biology 99, 155165. 
Sweeney, G. E., Watts, D. J. \& Turnock, G. (1987). Differential gene expression during the amoebalplasmodial transition in Physarum. Nucleic Acids Research 15, 933-945.

Theurkauf, W. E., Baum, H., Bo, J. \& Wensink, P. C. (1986). Tissue-specific and constitutive $\alpha$ tubulin genes of Drosophila melanogaster code for structurally distinct proteins. Proceedings of the National Academy of Sciences of the United States of America 83, 8477-8481.

Towbin, H., Staehelin, T. \& Gordon, J. (1979). Electrophoretic transfer of proteins from polyacrylamide gels to nitrocellulose sheets: procedure and some applications. Proceedings of the National Academy of Sciences of the United States of America 76, $4350-4354$.

TURnock, G., Morris, S. R. \& DeE, J. (1981). A comparison of the proteins of the amoebal and plasmodial phases of the slime mould, Physarum polycephalum. European Journal of Biochemistry 115 , 533-538.
Uyeda, T. Q. P. \& Kohama, K. (1987). Myosin switching during amoebo-plasmodial differentiation of slime mold, Physarum polycephalum. Experimental Cell Research 169, 74-84.

Von-Stosch, H. A., Van Zul-Pischinger, M. \& DERSCH, G. (1964). Nuclear phase alternance in the myxomycete Physarum polycephalum. In Abstracts of the 10th International Botanical Congress, Edinburgh, pp. 481-482.

WHEALS, A. E. (1970). A homothallic strain of the myxomycete Physarum polycephalum. Genetics 66, 623-633

Youngman, P. J., Adler, P. N., ShinNick, T. M. \& HolT, C. E. (1977). An extracellular inducer of asexual plasmodial development in Physarum polycephalum. Proceedings of the National Academy of Sciences of the United States of America 74, 1120 1124. 